HISTORIA:

International Journal of History Education, Vol. XIV No. 1 (June 2013)

\title{
THE DEVELOPING OF SOCIO-DRAMA MODEL OF LEARNING BY USING THE THEATER MEDIA IN HISTORY EDUCATION PROGRAM STUDY, FKIP UNSRI
}

\author{
Kiagus Syarifuddin ${ }^{1}$
}

\begin{abstract}
This research aimed to develop of history learning process by using the model of sociodrama with the theater media. The method that used by this research was the development and research method with the instructional development model developed by Atwi Suparman. The struggle of emancipation of RA Kartini is the subject which to be developed and packed in model of socio-drama with the theater media. Before the implentation of the instructional activity, the researcher with the help of the expert doing the validation to the script of drama and the instructional design. The script which had been evaluated were experimented to the student one to one and also to small group and continued by revisions. The script which had been already revised re-experimented in the research through by doing some casting to chose the player, and prepare the artistic stuff. The student do the exercise outside the class hour, performance in front of the class and end with the little discussion.
\end{abstract} model.

Key words: Socio-drama model, learning history process, development instructional

Ki Agus Syarifuddin, lecturer of the History Education Program Study of the Sriwijaya University. For academic interest, the author can be contacted through the office address: Kampus Unsri Indralaya, Palembang-Prabumulih Street Km 32. 
KIAGUS SYARIFUDIN,

The Developing of Socio-Drama model of Learning Using the Theater Media in History Education Program Study, FKIP Unsri.

\section{Introduction}

Education is the universal activity for human kind, it is the part of any kinds of cultures. The presentation of education interrelated with the aims of education that want to be reached. All those purposes proved by the presentation of education in our environment (Indonesia society). Many effort, have been taken for the realization of educational purposes by the government, such us through increasing the quality of education which one of its part was using the effective model of learning that suitable for the educational purposes. The good teaching and learning process are needed to increase the quality of education. Hamalik (2008:28) states that: "a process of individual behavioral is changed by the interaction with the environment."

Sudjana (2004:184) explains that learning is the process of interaction showed by the learning process in the self of students who has indicated by the behavioral change of learning experiences. It means that learning is a complex process that happens in human kind and continues as long as their life. One of its sign that the one has learned is showed by the behavioral changes in their selves, it caused by the purposes of education whose not only limited to the development of knowledge but also to the shaping of the creative and innovative mind set. That purposes have pushed to developing the learning model which enable to participating the student with their optimal potential in learning process, that provide the student to be able to think critically, confident, brave to speak, and enable to interact in teaching and learning process.

By this process of teaching and learning process students are hoped to be able to reach the achievements and to compete with one another to reach the good result of learning process. There are many kind of model that suitable in increasing the effective and efficient in implementing a good learning and teaching process done by the teacher, one of them is the model of socio-drama. It is the model of teaching and learning where the students demonstrate any kind of behavior and facial expressions of personal in social relationship.

At the present, the model of sociodrama is rarely implemented by the history education lectures. Commonly they used the classical method such us discussion, and question-answer method. In the model of socio-drama the students are given the chance to demonstrate the behaviors, attitudes, or identification of personality that commonly founded in the daily social relationships. This method can help the student to activating the psychological ensures of their self, such us observing, remembering, developing enthusiasm, and awareness, thinking, and doing their fantasy in the process of teaching and learning.

In this socio-drama model the writer developed the theater media. Theater is the story of human life and the humanism that is presented in the performance, who is watched by the people from the media of movement, talking, and acting; with or without decoration; and based on the written script with or without back songs (Azhari, 2009: 3). Theater media mixes any kinds of ensured artistic such us, painting, dancing, music, stage art, lighting, acting, make up, and costume.

The using of socio-drama model with theater media is hoped to be enable the student to grow their personality so as to 
have the patriotism, heroism, nationalism, and wisdom, through history, feeling, soul, and spirit of the student will be well stimulated. Based on the observation in the education history program study of the faculty of social study, the media was lack of model varieties. So that is why, the writer is interested to develop the method of socio-drama especially the one using the theater media.

\section{The Socio-drama learning Model by Using the Theater Media}

Djamarah $(2008,81)$ "the model of socio-darama is the teaching way that gives the chance to students to do the activity and play the specific parts in social life". In sociodrama process the students are exercised to be competent in dramatizing and expressing some indetified personalities". This model pointed to the development of ability of the students in understanding the script provided by the lectures (as director) through doing surgical script. The process of player searching by player casting. After that, the director with the crew make preparing for some artistic preperation with the theater media, such us make up, costume, music direction, lighting, stage act, and drama exercise.

A part of students played as the actor and actress, and another taking some job the sound man, and the crew of performing, and the last keep as the watchers or audience. After the performing, all the students are invited to the discussion and pushed to make some evaluation to the last performance. After that students and lecturer make of discussion.
The Diagram of the plot of Socio-drama learning model commonly presented such this Diagram 12.1:

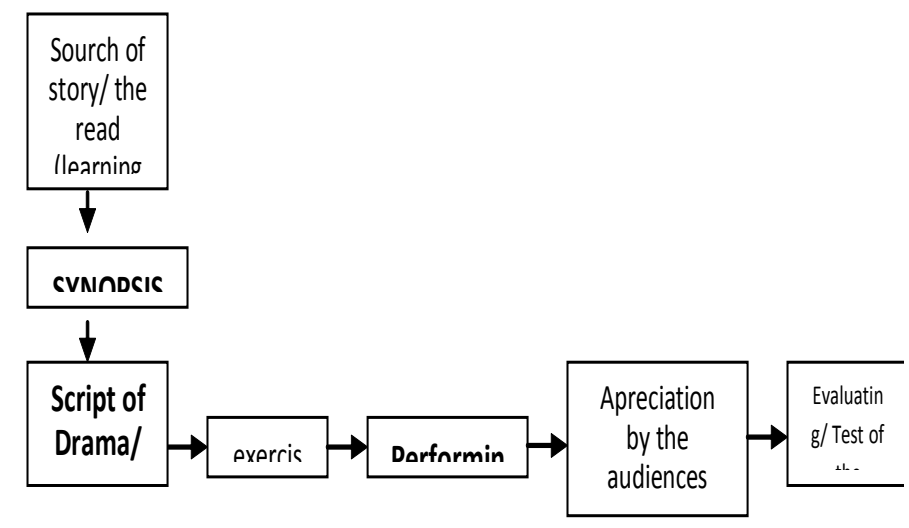

\section{The Steps of Learning}

1. The writing of the drama/theater script. The script is written based on the reading sources made as drama script/parts.

2. After the script is finished, the lecture distributes the script to every student in his class for doing script surgical by observing and understanding the plot, the characteristic, and the main of the story line.

3. Casting, is doing by teacher/lecture:

- The students are interpreting the story line.

- Reading the dialog (drama take reading)

- Understanding the plot, character and parts in the drama.

- The lecturer is observing the skills of the students in understanding 
KIAGUS SYARIFUDIN,

The Developing of Socio-Drama model of Learning Using the Theater Media in History Education Program Study, FKIP Unsri.

the plot, story line, character, and the physical and psychological similarity to the characters.

4. Artistic Preparation

- Exercises, in concentration, vocal arrangement, body arrangement, improvisation, and observation.

- $\quad$ Minimize make up and costume.

- Lighting

- Music direction, theinstrumentalia from the simple musical instruments such as guitar, drum, and voice effects.

- Stage Act is made with simflicity, by arranging the beches in the class and the black veil as background.
5. Rehearsalfor seeing the pra-perspective of the performance, such as the story line, the plot, the character, and many other artistic ensures.

6. Performing

- The students are performing the drama in front of the class, while another appreciating it as audiences.

- The Lecturer directs the students for joining and watching the drama on the theater media.

7. Evaluation (the Test of the Learning Results)

- $\quad$ The students give some critics and comments and with the help of the teacher they make conclusion.

- $\quad$ The test of the learning results.

\section{The Diagram 12.2 The Diagram of the Plot of Socio Drama Learning Model by Using Theater Media}

(Azhari, 2009:41-44)

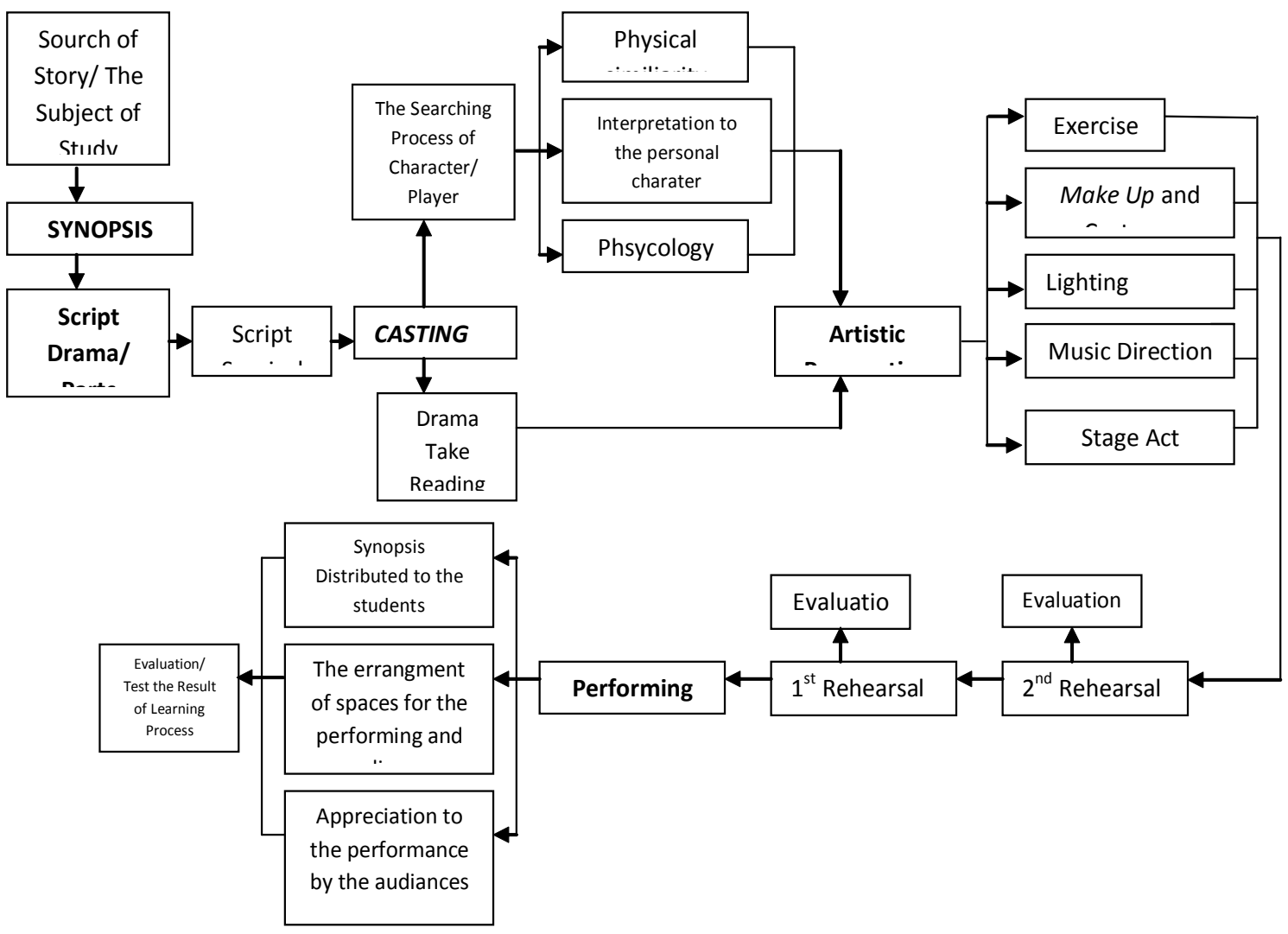


The Correlation among the Implication of the Model and the Student Motivation and Their Activities, and the Result of History Learning Process

One of the function of the history learning is to make students fell the past events preserved in the cultural tradition of the pasts. History learning implemented the socio-drama model with the media of theater gives the chance to the students to do the activities, play the specific parts that come from their daily life. In the sociodrama process students are educated to be skillful in dramatizing and expressing the character that they should identify. During the learning process the event merely made as what it is true.

In the learning process of the sociodrama model, students not only listening what the teacher is explaining, but also they were building the knowledge throug their experiences (learning by doing). Media theater exercises the students to implementing socio-drama learning model by playing the parts and trying to be more critical to the story as audiences. Players and audiences they both have actively involve during different activities.

The students who become the player, they do the moving activity because they directly have experienced in playing the character. Every players have to be able to performe the situations of the characters as real. Except in the moving activity, they are doing the oral activity, listening, thinking, and solving the problem. The students who became audiences they are doing many activities personally. They are doing visual activity, listening, preparing their mental and emotional to be active as much as the players.
Student who become the player or audiences, they both had the same hard work. As the players they are pushed for doing the best actions in front of their friends, and performing every character closed to the real history. Students as audiences should watch carefully to every parts of the drama. They are pushed to know in detail all the performing.

Based on the explanations above, it was shown that the history learning process implemented in socio-drama method using the media of theater could increase the activities of the students. So they are pushed to know more about how the result of the performance of their friends. After the students experience what they did in drama, they would be in fold into personal behavioral change in many field of human ability such as cognition, psychomotor and affection.

The history learning by implementing the socio-drama model using the theater media could develop the students activities and motivate the students to learn. The learning process is doing in advance to prepare the performing on the stage by doing exercise outside the class hours. It shows that this learning directs to the optimal learning process. Students are doing any activities in learning history which could raise up the motivation for increasing the result of study.

\section{Research Method}

The writer uses research and development in making this writing. Research and development is the research method that commonly used as the research method to make the specific product, and to test the affectivity of it. There are a lot of products of education such as teaching 
KIAGUS SYARIFUDIN,

The Developing of Socio-Drama model of Learning Using the Theater Media in History Education Program Study, FKIP Unsri.

method, educational media, etc. (Sugiyono, 2008: 412). This research used the Instructional Development Model (IDM) or Model Pengembangan Instruksional developed (MPI) by Atwi Suparman. The plot of Instructional Development Model (IDM) is show on the following diagram of collecting data tecnique of this research are: a) observation, to see the activity of the students in the learning process; b) Test, to measure the result of learning process of students.

12.1:

\section{The Diagram 12.3 The plot of \\ Instructional Development Model \\ (IDM) (Suparman, 2004:16)}

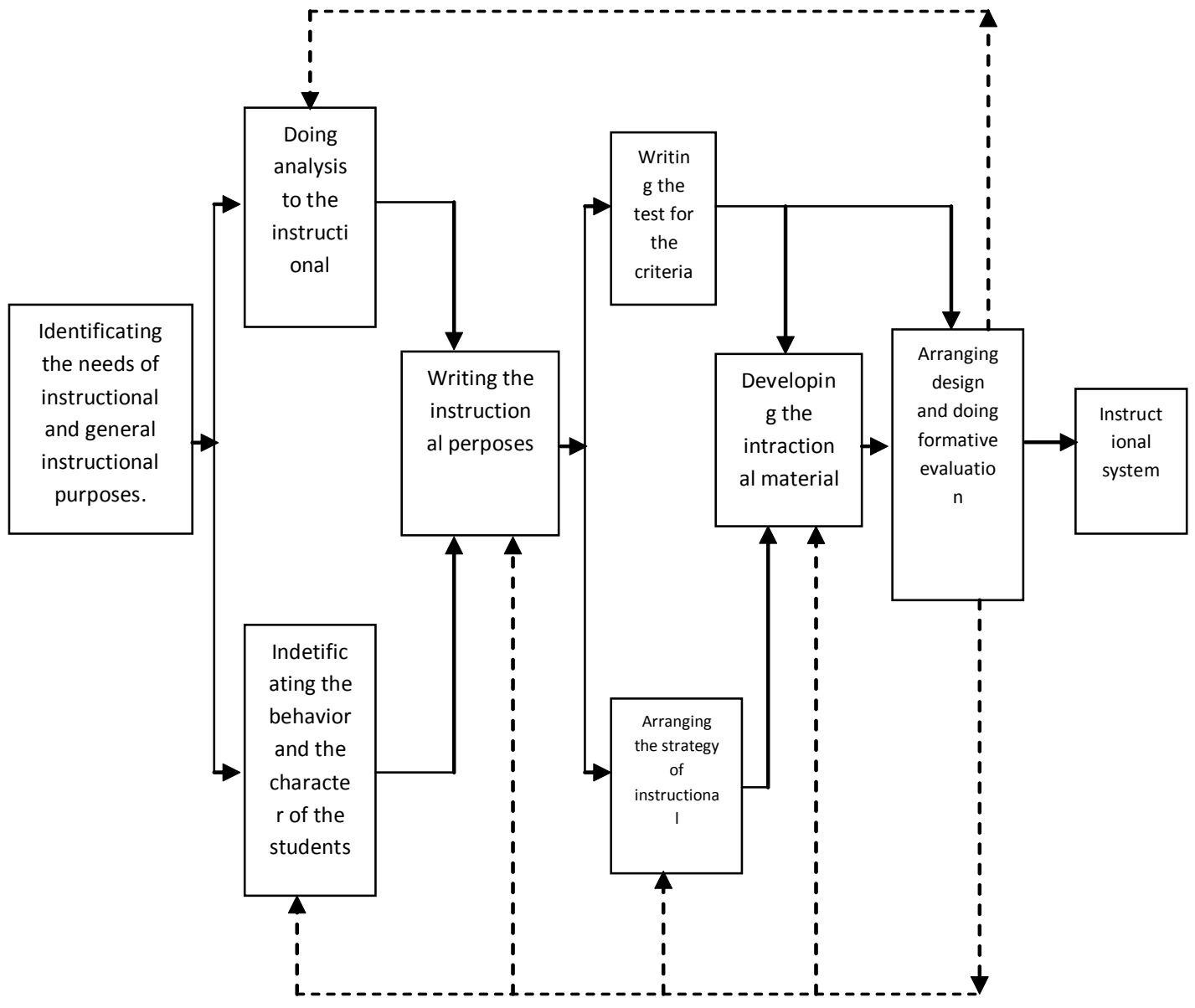

This research took the area researh in the history education program of FKIP USNRI Indaralaya, Palembang. The subject was the students of the history education program of FKIP USNRI Indaralaya. The

\section{Main Result}

The observations are done when the history learning using socio-drama model by the theater media was used in the history learning process. The observations were done to the players and the audiences. 
Based on the result of observations during the learning process, it was showed that the average of students activity were in the group of active. That was indicated by the average score in the number of 80 percent. In another way the observation showed that the rate number of activity of the audiences reaches the 50 percent. That average showed that the activity of audiences ware in the active category.

Based on the analysis above, it may be concluded that students either as players or as audiences had the same chance to be more active when they followed the learning process by the socio-drama model with the theater media.

After performing, the lecture took the students to join the discussion in groups to discuss the last performance. After that, the lecturer gave the paper test for evaluation. The test was done for assessing the result of the learning process in understanding the subject provided by their learning experiences with the socio-drama model. The tests were given twice, and the result showed that the average of student activity when they followed the learning process by the socio-drama model with the theater media reached the 70 percent, it was in the high category.

From the result of the observations above, it may be concluded that the learning process with socio-drama model using the theater media gave the effect to the learning result of the students.

\section{Developing the Socio-Drama Model of Learning Using the Theater Media In the History Learning Process}

The process of the development of the socio-drama model of learning by using the theater media in the history learning process consists of eight steps. 1) Analyzing the needs and writing the basic competent; 2) instructional analyzing; 3) Arranging the students character; 4) defining the indicators; 5) arranging the test; 6) arranging the instructional strategy; 7) Developing the instructional materials; 8) making the formative design evaluation.

The developing of socio-drama model by using the theater media has passed the eight steps above. The product of it is the material and the instructional activities on the subject of the history of Kartini. The history learning by socio-drama model is valid, because it is experienced before it is done in the class, the material of study such as the script of drama and the instructional has been previously evaluated by the expert.

The script validated by the expert in the field was experienced to the students individually in the small groups. The result of that experience showed that the script that had been revised from the formative evaluation by the expert, students read the script and did the exercise with the groups.

After the script of drama finished to be evaluated and concluded as valid, the script was then used as the main material of the instructional for socio-drama model of learning by using the theater media. The next step was casting. Before the casting students read the scripts, then they were asked to interprete the character that would be played in the drama.

For presenting the socio-drama learning process using the theater media, exercise and rehearsal were done outside the class hours. This was for anticipating the less times for socio-drama it as in line with the perspective of Sriyono (1992-117) 
KIAGUS SYARIFUDIN,

The Developing of Socio-Drama model of Learning Using the Theater Media in History Education Program Study, FKIP Unsri.

who said that the times ware limited so that way the chance to be full rolled would be unfulfilled.

\section{The students activities during the Learning Process}

The implication of the socio-drama in the class Enviroment became the stage and the simple theater. But student as players were still nervous when they were performing it. Sriyono (1992:117) states that the shyness has caused the abnormal condition to the role that they are played. And it effects to the less production of the sounds when they are performing.

\section{The result of learning activity process}

The final result of socio-drama model using the Theater media was evaluated. The aims was to see how the socio-drama model could effect the learning result.

Reading the synopsis of drama made students know greatly the subject of learning, with the socio-drama model students could understanding and learn the subject especially about Kartini. This happening in line with thing as way as with the perspective of Rustiyah (2009:91) who state that the technique of socio-drama will ease student to be more attracted into the subject matter, because they could play their own role as part. Sudjana support (2004: 37) the learning process should be optimally be done and made by the students to obtain the optimum result. There is a correlation between the process and result. The higher the conditional situation for learning, the higher the result and product of learning.

\section{Conclusion}

Based on the result of the research it may be concluded that the experiment and validation to the students have shown that the material subject such the script and the activity of learning provided by the sociodrama model using theater media in the subject matter of the history of Kartini was valid. Based on the observation, the student activities either as player or as the audiences were categorized active in the process of learning. The overall result of the learning processes through using the socio-drama model with theater media were very good.

\section{REFERENCES}

Abror, A. R. (1994). Psikologi Pendidikan. Yogyakarta: Tiara Wacana.

Ahmadi, A and Prasetyo, Joko Tri. (1997). Strategi Belajar Mengajar. Bandung: Pustaka Setia.

Arikounto, S. (1993). Dasar-Dasar Evaluasi Pendidikan. Jakarta: Bumi Aksara.

Arikounto, S. (2002). Prosedur Penelitian

Suatu Pendekatan Praktek. Jakarta: Rineka Cipta.

Azhari, M. (2009). Manajemen Teater. Palembang: Penerbit Universitas Sriwijaya.

Djaali, P. (2004). Pengukuran dalam Biendg Pendidikan. Jakarta: Program Pascasarjana Universitas Negeri Jakarta.

Djamarah, S. (1994). Prestasi Belajar Peserta Didik dan Kompetensi Guru. Jakarta: Bumi Aksara.

Departemen Dalam Negeri Republik Indonesia. (2003). Undang-Undang 
No.2O Tahun 2003 Tentang Sistem Pendidikan Nasional. Jakarta: Departemen Dalam Negeri Republik Indonesia.

Depdikbud. (1995). Pengajaran Sejarah (Kumpulan Makalah Simposium). Jakarta.

Depdiknas. (2004). Pedoman Khusus Mata Pelajaran Sejarah Kurikulum 2004. Jakarta.

Gazalba, S. (1981). Pengantar Sejarah sebagai Ilmu. Bhatara Karya Aksara: Jakarta.

Gredler, E B.(2003). Belajar dan Membelajarkan. Jakarta: Raja Grafindo Persada.

Hamalik, O. (2001). Kurikulum dan Pembelajaran. Jakarta: Bumi Aksara.

Hamalik, O. (2008). Proses Belajar Mengajar. Jakarta : Bumi Aksara.

Hariyono. (1995). Mempelajari Sejarah Secara Efektif. Dunia Pustaka Jaya: Jakarta.

Ibrahim dan Syaodih, N. (2003). Perencanaan Pengajaran. Jakarta: Rineka Cipta.

Kartikaningsih, D. (2007). Pengaruh Motivasi Belajar terhadap Prestasi Belajar Praktik Motor Listrik Siswa Jurusan Teknik Listrik di SMK Migas Серu. Semarang: Universitas Negeri Semarang.

Margono. (1996). Metodologi Penelitian Pendidikan. Jakarta: Rineka Cipta.

McMillan, J.H. and Schumacher, S. (2010) Research in Education, Evidence-Based Inquiry (Seventh edition). New Jersey: Pearson Education. Inc.

Miles, M., dan Huberman, M. (1992). Analisis Data Kualitatif: Buku Sumber tentang Metode-metode Baru. Penerjemah: Tjetjep Rohendi
Rohidi, Jakarta: UI Press. Nasution, dkk. (2007). Evaluasi Pembelajaran Matematika. Jakarta: Universitas Terbuka.

Natawijaya, R. (1985). Cara Belajar Siswa Aktifand Penerapannyadalam Metode Mengajar: Depdikbud.

Priyanto, D. (2008). Mandiri Belajar SPSS. Jakarta: Buku Kita

Roestia. (1991). Strategi Belajar Mengajar. Jakarta: Rineka Cipta.

Sardiman, A. M. (2003). Interaksi dan Motivasi Belajar. Jakarta: Raja Grafindo Persada.

Sudjana, N. (1998). Penelitian dan Penilaian Pendidikan. Bandung: Sinar Baru.

Sudjana, N dan Ibrahim, R. (2001). Penelitian dan Penilaian Pendidikan. Bandung: Sinar Baru Algensindo.

Surya, M. (2004). Psikologi Pembelajaran dan Pengajaran. Bandung: Pustaka Bani Qurais.

Suryosubroto, B. (2002). Proses Belajar Mengajar di Sekolah. Jakarta: Rineka Cipta

Syah, M. (2006). Psikologi Pendidikan: Suatu Pendekatan Baru. Bandung: Remaja Rosdakarya

Sudjana, N. (1989). Dasar-Dasar Proses Belajar Mengajar. Bandung: Sinar Baru Algesindo.

Suherman, E. (1994). Evaluasi Proses and Hasil Belajar. Jakarta: Depdikbud

Sugiyono. (2005). Statistika untuk Penelitian. Bandung: Alfabeta.

Sugiyono. (2008). Metode Penelitian Pendidikan. Bandung: Alfabeta.

Suparman,A.(2004).DesainInstruksional. Jakarta: Universitas Terbuka.

Slameto. (2003). Belajar dan FaktorFaktor yang Mempengaruhinya. Jakarta: Rineka Cipta. 
KIAGUS SYARIFUDIN,

The Developing of Socio-Drama model of Learning Using the Theater Media in History Education Program Study, FKIP Unsri.

Sriyono, dkk. (1992). Teknik Belajar Mengajar dalam CBSA. Jakarta:PT Rineka Cipta

Suyoto, A. (2009). Dasar-Dasar Apresiasi Drama. Yogyakarta. Diakses Februari.

Usman, U. (2000). Menjadi Guru

Profesional. Bandung: PT Remaja Rosdakarya

Purwanto,N.(2003).PsikologiPendidikan.

Bandung: Remaja Rosdakarya.
Widja, I. G. (1991). Pendidikan Sejarah dan Tantangan Masa Depan. Singaraja: FKIP Universitas Udayana.

Winkel, W.S. (1987). Psikologi Pendidikan. Jakarta: Gramedia.

Wiriaatmadja, R. (2002). Pendidikan Sejarah di Indonesia. Bandung: Historia Utama Press. 